\title{
Peranan Konsorsium Isolat Bakteri Resisten Logam Berat untuk Menurunkan Kandungan Zn, Fe, dan Mg pada Cumi, Udang, dan Ikan
}

\section{The Role of Heavy Metal Resistant Bacteria Isolate Consortium to Reduce Zn, Fe and Mg Content in Squid, Shrimp and Fish}

\author{
ADOLF J. N. PARHUSIP1, JESSICA XAVERIA ${ }^{1}$, WAHYU IRAWATI ${ }^{2 *}$ \\ 1)Departemen Teknologi Ilmu Pangan, Universitas Pelita Harapan, M.H. Thamrin Boulevard 1100, Lippo Karawaci, \\ Tangerang 15811, Banten, Indonesia \\ ${ }^{2)}$ Departemen Pendidikan Biologi, Universitas Pelita Harapan, M.H. Thamrin Boulevard 1100, Lippo Karawaci, \\ Tangerang 15811, Banten, Indonesia \\ Email:w.irawati3@gmail.com
}

\begin{abstract}
Increased contamination of heavy metals in aquatic products such as shrimp, squid, and fish can occur due to industrial waste. Heavy metals cannot be digested so they will accumulate in the body of animals and humans. Excess heavy metals in the body can cause death. Bioremediation using bacteria can reduce heavy metal contamination. Some microorganisms have the ability to resist heavy metals such as, Acinetobacter sp. IrC1 and Acinetobacer sp. IrC2 which were isolated from the activated sludge of the Rungkut-Surabaya industry, Indonesia. This study aims to determine the role of the consortium Acinetobacter sp. IrC1 and Acinetobacer sp. IrC2 in reducing the concentration of Zn, Fe, and $\mathrm{Mg}$ in squid, shrimp, and fish. Research methods include: 1) making a bacterial growth curve, 2) analysis of heavy metals in shrimp, squid, and fish, 3) testing the ability of a bacterial consortium to reduce metal concentration in squid, shrimp, and fish, 4) analysis of decreasing heavy metal concentration by using a bacterial isolate consortium. The results show that the selected comparison between consortium of Acinetobacter sp. IrC1 dan Acinetobacter sp. IrC2 was 66.66\%:33.33\% which can reduced heavy metals of $\mathrm{Zn}, \mathrm{Fe}$, dan $\mathrm{Mg}$ in shrimps, squid, and fish with the range of $91.69 \%$ to $99.82 \%$.Other heavy metal contained in the aquatic products of shrimp, squid, and fish were $\mathrm{Cd}, \mathrm{Co}, \mathrm{Cr}, \mathrm{Cu}$, and $\mathrm{Hg}$.
\end{abstract}

Keywords: Acinetobacter sp, bacteria, fish, shrimp, squid

\begin{abstract}
ABSTRAK
Peningkatan cemaran logam berat pada hasil perairan seperti udang, cumi, dan ikan dapat terjadi karena limbah industri. Logam berat tidak dapat dicerna sehingga akan terakumulasi di dalam tubuh hewan maupun manusia. Kelebihan logam berat di dalam tubuh dapat mengakibatkan kematian. Bioremediasi dengan menggunakan bakteri dapat mengurangi cemaran logam berat. Beberapa mikrorganisme mempunyai kemampuan resistensi terhadap logam berat seperti, Acinetobacter sp. IrC1 dan Acinetobacer sp. IrC2 yang diisolasi dari lumpur aktif industri Rungkut-Surabaya, Indonesia. Penelitian ini bertujuan untuk mengetahui peranan Konsorsium Acinetobacter sp. IrC1 dan Acinetobacer sp. IrC2 dalam menurunkan kandungan $\mathrm{Zn}$, Fe, dan $\mathrm{Mg}$ pada cumi, udang, dan ikan. Metode penelitian meliputi: 1) pembuatan kurva pertumbuhan bakteri, 2) analisis logam berat pada udang, cumi, dan ikan, 3) uji kemampuan konsorsium bakteri dalam menurunkan kandungan logam pada cumi, udang, dan ikan serta 4) analisis penurunan kandungan logam berat dengan menggunakan konsorsium isolat bakteri. Hasil penelitian menunjukkan bahwa perbandingan konsorsium Acinetobacter sp. IrC1 dan Acinetobacter sp. IrC2 terpilih adalah 66,66\%:33,33\% dengan nilai presentase penurunan logam berat ( $\mathrm{Zn}, \mathrm{Fe}$, dan $\mathrm{Mg}$ ) pada hasil perairan udang, cumi, dan ikan memiliki interval 91,69\% hingga 99,82\%. Acinetobacter pittii memiliki nilai presentase penurunan logam berat $\mathrm{Zn}$, $\mathrm{Fe}$, dan $\mathrm{Mg}$ pada hasil perairan udang, cumi, dan ikan yang lebih rendah, yaitu memiliki interval $87,87 \%$ hingga $99,50 \%$. Kandungan logam berat lain yang terkandung di dalam hasil perairan udang, cumi, dan ikan adalah $\mathrm{Cd}, \mathrm{Co}, \mathrm{Cr}, \mathrm{Cu}$, dan $\mathrm{Hg}$.
\end{abstract}

Kata kunci: Acinetobacter sp., bakteri, cumi, ikan, udang

\section{PENDAHULUAN}

Berdasarkan Laporan Kantor Pengkajian dan Lingkungan Hidup (KPPL) DKI Jakarta tahun 2013, limbah yang masuk ke perairan
Teluk Jakarta $97,82 \%$ yakni $1.632 .896 \mathrm{~m}^{3} /$ tahun berasal dari kegiatan industri produksi seperti industri pengemasan makanan kaleng, industri zat pewarna (tekstil, percetakan, produksi 
kertas), industri logam (komputer, mesin, peralatan listrik, baterai), dan industri manufaktur ${ }^{(1)}$. Teluk Jakarta merupakan muara dari tiga belas sungai yang mengairi sepanjang wilayah Bogor, Depok, Tangerang, dan DKI Jakarta. Tiga belas sungai tersebut antara lain Sungai Angke, Sungai Ciliwung, Sungai Sunter, Sungai Bekasi, Sungai Cikarang, Sungai Cakung, cabang Sungai Citarum, Sungai Cipinang, Sungai Kamal, Sungai Ancol, Sungai Blencong, Sungai Grogol, dan Sungai Pesanggrahan (2). Menurut Heni Agustina sebagai Kepala Subdit Inventarisasi dan Mutu Laut, Direktorat Pengendalian Pencemaran dan Kerusakan Lingkungan Pesisir dan Laut, Kementerian Lingkungan Hidup dan Kehutanan (KLHK), kandungan logam berat di beberapa muara sungai Jakarta telah melebihi ambang batas. Sungai-sungai tersebut bermuara di Muara Kamal, Ancol(3).

Pada tahun 2012, kandungan $\mathrm{Pb}$ dan $\mathrm{Cd}$ pada air di Muara Kamal secara berturut-turut adalah 0,16 dan $0,01 \mathrm{ppm}$. Nilai tersebut telah melebihi baku mutu air laut untuk hasil perairan yaitu 0,008 ppm untuk $\mathrm{Pb}$ dan 0,001 ppm untuk $\mathrm{Cd}^{(4,5)}$. Pada tahun 2009 , kandungan $\mathrm{Hg}$ pada sedimen di Muara Kamal adalah 2,173 $\mathrm{ppm}^{(6)}$, Nilai tersebut telah melebihi ambang batas yang ditentukan oleh IADC/CEDA (1997) yaitu sebesar $1,6 \mathrm{ppm}^{(7)}$.

Masuknya cemaran fisik, kimia, atau biologi ke dalam perairan dapat membahayakan hasil produk perairan. Logam berat dapat masuk ke dalam tubuh hewan perairan seperti udang, cumi, dan ikan melalui sistem pernafasan seperti insang( ${ }^{(8)}$. Udang, cumi, dan ikan akan mengakumulasi logam berat dalam jaringan tubuhnya. Semakin tinggi kandungan logam berat pada perairan, semakin tinggi pula kandungan logam berat yang terakumulasi di dalam tubuh hewan tersebut. Akibatnya jika masyarakat mengkonsumsi hasil perairan yang tercemar logam berat, masyarakat akan mengakumulasikan logam berat tersebut di dalam tubuh mereka, sehingga dapat menimbulkan bahaya bagi kesehatan masyarakat ${ }^{(9)}$.

Bioremediasi adalah penggunaan mikroorganisme yang telah dipilih untuk ditumbuhkan pada polutan tertentu, sebagai upaya untuk menurunkan kadar polutan tersebut ${ }^{(10)}$. Mikroorganisme yang terpapar logam berat mencari cara untuk bertahan hidup. Terdapat berbagai macam mekanisme resistensi bakteri terhadap logam berat antara lain adalah biosorpsi dan bioakumulasi(11). Biosorpsi adalah mekanisme resistensi bakteri yang terjadi karena adanya interaksi fisikokimia antara dinding sel bakteri dengan ion logam berat. Bioakumulasi adalah mekanisme resistensi bakteri dengan cara mengakumulasi logam berat di dalam sel(12).

Bakteri pereduksi logam berat yang akan digunakan pada penelitian ini adalah Acinetobacter sp. IrC1 dan Acinetobacter sp. IrC2. Hasil peneltian pada beberapa bakteri resisten tembaga yang diisolasi dari limbah industri di Rungkut Surabaya menunjukkan bahwa konsorsium Acinetobacter sp. IrC1 dan Acinetobacter sp. IrC2 mempunyai kemampuan akumulasi tertinggi dibandingkan bakteri resisten yang lain seperti Acinetobacter pittii (13). Kedua bakteri tersebut adalah bakteri pereduksi logam berat yang diisolasi dari lumpur aktif industri penanganan air limbah organik Rungkut-Surabaya, Indonesia ${ }^{(14)}$. Kombinasi atau konsorsium dari bakteri tersebut memberikan hasil yang lebih maksimal dibanding bakteri tunggal|(15).

Penelitian ini bertujuan untuk mencari perbandingan konsorsium terbaik antara Acinetobacter sp. IrC1 dan Acinetobacter sp. IrC2 dalam mereduksi logam berat di dalam sampel hasil perairan berupa udang jerbung, cumi, dan ikan mujair. Acinetobacter pittii digunakan sebagai kontrol bakteri pereduksi logam berat sehingga pada akhir penelitian akan dibandingkan antara konsorsium terpilih bakteri isolat dengan perlakuan tunggal bakteri komersiil dalam mereduksi logam berat pada sampel hasil perairan berupa udang jerbung, cumi, dan ikan mujair.

\section{BAHAN DAN METODE}

\subsection{Bahan}

Bakteri diisolasi dari lumpur aktif PT SIER Surabaya. Medium yang digunakan adalah Luria Bertani (LB) dengan persentase $2 \%$ dan agarindo $2 \%$.

\subsection{Metode Penelitian}

\subsubsection{Pembuatan Kurva Pertumbuhan Bakteri}

Satu ose kultur stok diambil, lalu diinokulasikan ke dalam tabung berisi $10 \mathrm{ml}$ LB cair dan diinkubasi selama 24 jam pada suhu $37^{\circ} \mathrm{C}$. Kultur yang telah disegarkan diambil $1 \mathrm{ml}$ dan diinolukasikan ke dalam tabung berisi $9 \mathrm{ml}$ LB cair, lalu diinkubasi pada suhu $37^{\circ} \mathrm{C}$ sesuai waktu optimal yang didapatkan dari tahap penentuan kurva pertumbuhan bakteri.

Sebanyak $1 \mathrm{ml}$ kultur yang telah disegarkan diinokulasikan pada tabung berisi $9 \mathrm{ml}$ LB cair. Inkubasi tabung tersebut pada suhu $37^{\circ} \mathrm{C}$. Pertambahan jumlah bakteri diamati pada jam ke-0, 2, 4, 6, 8, 10, 12, 24, dan 30 dengan perhitungan total bakteri pada media LB agar. 


\subsubsection{Analisis Logam berat pada udang, cumi, dan ikan}

Penelitian pendahuluan dilakukan untuk menentukan kandungan logam berat awal di dalam sampel. Sampel berupa udang jerbung, cumi, dan ikan mujair terlebih dahulu dikeringkan dalam oven dengan suhu $105^{\circ} \mathrm{C}$, diperkecil ukurannya dengan dry blender, lalu didestruksi agar logam berat terlepas dari ikatannya (ikatan kimia) sehingga AAS bisa mendeteksi logam yang berwujud ion.

\subsubsection{Uji kemampuan konsorsium bakteri dalam menurunkan kandungan logam pada cumi, udang, dan ikan.}

Sebanyak 3\% kultur bakteri diinokulasikan ke dalam botol kaca berisi 1 gram sampel dan $49 \mathrm{ml}$ LB cair kemudian diinkubasikan dengan penggojogan $200 \mathrm{rpm}$ pada suhu $37^{\circ} \mathrm{C}$ selama 24 jam. Hasil penelitian sebelumnya tentang konsorsium bakteri yang akan diteliti menunjukkan bahwa konsorsium Acinetobacter sp. IrC1 dan Acinetobacter sp. IrC2 dengan perbandingan 1:1 lebih baik kemampuan akumulasinya dibandingkan bakteri tunggal karena bakteri dengan spesies yang sama akan saling bekerjasama secara sinergisme dalam melakukan mekanisme resistensi ${ }^{(13)}$. Penelitian berikut ini akan menguji lebih lanjut mengenai perbandingan konsorsium dengan harapan memperoleh hasil yang lebih optimal.

Perlakuan konsorsium bakteri adalah:

1. Acinetobacter sp. IrC1 (100\%) sebagai kontrol

2. Acinetobacter sp. IrC2 (100\%) sebagai kontrol

3. Acinetobacter pittii (100\%) sebagai kontrol

4. Acinetobacter sp. IrC1 : Acinetobacter sp. IrC2 (50\%:50\%)

5. Acinetobacter sp. IrC1 : Acinetobacter sp. IrC2 $(33,33 \%: 66,66 \%)$

6. Acinetobacter sp. IrC1 : Acinetobacter sp. IrC2 (66,66\%:33,33\%)

7. Acinetobacter sp. IrC1 : Acinetobacter sp. IrC2 (40\%:60\%)

8. Acinetobacter sp. IrC1 : Acinetobacter sp. IrC2 (60\%:40\%)

\subsubsection{Analisis penurunan kandungan logam berat dengan menggunakan konsorsium isolat bakteri}

Sampel didestruksi dengan penambahan asam pekat secara berkala, yaitu $\mathrm{HNO}_{3} 65 \%$, $\mathrm{H}_{2} \mathrm{SO}_{4} 98 \%$, dan $\mathrm{H}_{2} \mathrm{O}_{2} 30 \%$. Sampel cumi membutuhkan 2 kali penambahan asam pekat, udang membutuhkan 3 kali penambahan asam pekat dan ikan 4 kali penambahan asam pekat. Setiap kali penambahan komposisi $\mathrm{HNO}_{3} 65 \%$, $\mathrm{H}_{2} \mathrm{SO}_{4} 98 \%$, dan $\mathrm{H}_{2} \mathrm{O}_{2} 30 \%$ adalah $30 \mathrm{ml}, 10 \mathrm{ml}$ dan $5 \mathrm{ml}$ (6:2:1). Destruksi dilakukan dengan pemanasan $310^{\circ} \mathrm{C}$ selama 15 menit dan pengadukan hinga berwarna larutan yang jernih atau bening. Analisis logam berat dilakukan dengan menggunakan spektrofotometer serapan atom. Penurunan kandungan logam berat dihitung dengan mengurangi kandungan logam berat pada sampel awal dan kandungan logam berat setelah kontak dengan bakteri resisten logam berat.

\section{HASIL DAN PEMBAHASAN}

\subsection{Hasil Kurva Pertumbuhan Kultur}

Kurva pertumbuhan bakteri dapat dilihat pada Gambar 1. Kurva pertumbuhan bakteri terdiri dari empat fase, yaitu fase lag atau adaptasi, fase logaritma atau eksponensial atau pertumbuhan, fase stasioner, dan fase kematian(17). Gambar 1 menunjukkan bahwa fase adaptasi yang dimiliki oleh Acinetobacter sp. IrC1, Acinetobacter sp. IrC2, dan Acinetobacter pittii cukup singkat, yaitu jam ke$0-2$. Fase eksponensial merupakan fase yang terjadi setelah fase adaptasi, ditandai dengan pembelahan sel-sel baru secara maksimum. Fase eksponensial ditentukan dengan peningkatan jumlah sel dari masa adaptasi ${ }^{(17)}$. Fase eksponensial yang dimiliki Acinetobacter sp. IrC1, Acinetobacter sp. IrC2, dan Acinetobacter pittii adalah jam ke 2-4. Pada penelitian ini akan digunakan jam ke-4 sebagai waktu optimum pertumbuhan bakteri. Jumlah sel Acinetobacter sp. IrC1, Acinetobacter sp. IrC2, dan Acinetobacter pittii pada jam ke 4 secara berturut-turut adalah $2,21 \times 10^{8} ; 1,82 \times$ 108; dan $1,74 \times 10^{8} \mathrm{CFU} / \mathrm{ml}$.

\subsection{Analisis Hasil Uji Kandungan Logam Berat pada cumi, udang, dan ikan}

Logam berat yang dianalisis dengan menggunakan AAS ada sembilan jenis, antara lain $\mathrm{Cd}$, Co, $\mathrm{Cr}, \mathrm{Cu}, \mathrm{Hg}, \mathrm{Fe}, \mathrm{Pb}, \mathrm{Zn}$, dan $\mathrm{Mg}$. Rata-rata kandungan logam berat pada sampel udang, cumi, dan ikan dapat dilihat pada Gambar 2.

Berdasarkan SNI (2009a), dapat disimpulkan bahwa jumlah logam berat $\mathrm{Cd}, \mathrm{Hg}$, dan $\mathrm{Pb}$ di dalam sampel udang jerbung, cumi, dan ikan mujair belum melewati batas maksimum yang ditetapkan sedangkan logam berat lain, memiliki ambang batas yang cukup bervariasi bergantung pada negara masing-masing ${ }^{(18)}$. Logam Co, Cr, dan $\mathrm{Cu}$ pada ketiga sampel tersebut secara berturut-turut adalah $<0,04,<0,05$, dan $<0,01$ ppm. Jumlah logam berat $\mathrm{Co}, \mathrm{Cr}$, dan $\mathrm{Cu}$ di dalam sampel udang jerbung, cumi, dan ikan mujair belum melewati ambang batas logam yang ditetapkan ICMR ${ }^{(19)}$.

Jumlah logam berat $\mathrm{Zn}$ dan $\mathrm{Mg}$ di dalam sampel udang jerbung, cumi, dan ikan mujair 
belum melewati batas wajar menurut USDA, sedangkan logam berat Fe di dalam sampel ikan mujair yaitu 6.43 ppm telah melewati batas wajar menurut USDA(20). Jumlah logam berat $\mathrm{Fe}$ di dalam sampel udang jerbung dan cumi belum melewati batas wajar menurut USDA ${ }^{(20)}$. Tubuh manusia tidak bisa mengekskresikan $\mathrm{Fe}$, sehingga $\mathrm{Fe}$ berlebih disimpan di dalam pankreas atau hati(21).

\section{Acinetobactersp. IrC1}

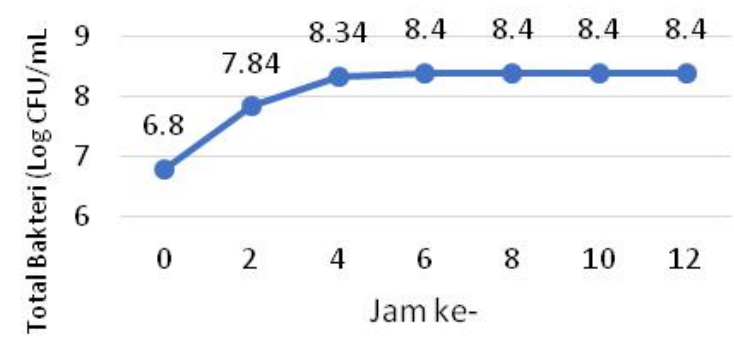

Acinetobactersp. IrC2

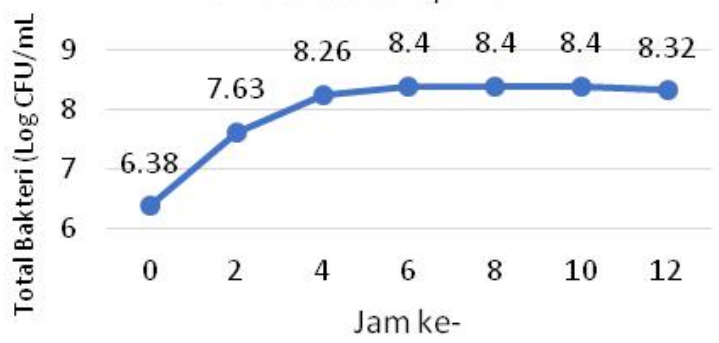

Acinetobacter pittii

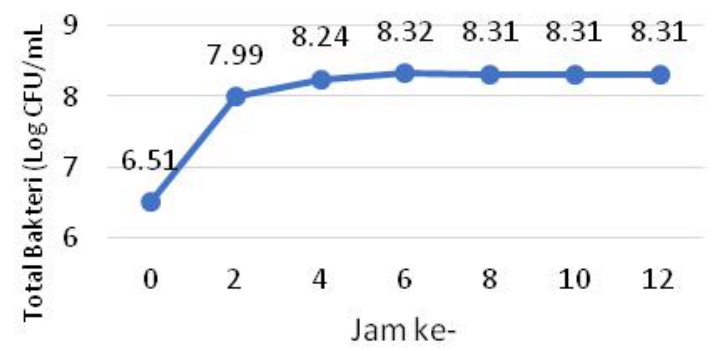

Gambar 1. Kurva pertumbuhan bakteri

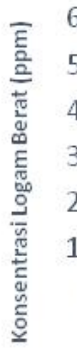

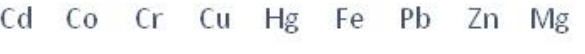

Logam Berat

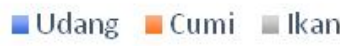

Gambar 2. Konsentrasi logam berat pada udang, cumi, dan ikan

\subsection{Kemampuan konsorsium bakteri dalam menurunkan logam berat}

Berdasarkan Gambar 3 Acinetobacter sp. $\mathrm{IrC} 1$ dengan Acinetobacter sp. $\mathrm{IrC2}$ (66,66\%:33,33\%) memiliki interval penurunan kandungan $\mathrm{Zn}$, Fe, dan $\mathrm{Mg}$ pada cumi, dan ikan mujair sebesar 91,69 hingga 99,82\% dengan rata-rata sebesar $97,87 \%$, sedangkan perlakuan bakteri komersil Acinetobacter pittii (100\%) memiliki interval penurunan sekitar 87,87 hingga $99,50 \%$ dengan rata-rata sebesar $96,17 \%$. Konsorsium terpilih yaitu Acinetobacter sp. IrC1 dengan Acinetobacter sp. IrC2 (66,66\%:33,33\%) memiliki hasil yang lebih tinggi dibandingkan Acinetobacter pittii (100\%). Hal ini dapat terjadi karena Acinetobacter sp. IrC1 dan Acinetobacter sp. IrC2 sudah beradaptasi dengan cemaran logam berat dalam jangka waktu yang lama di lingkungan. Kedua bakteri tersebut di laboratorium selalu ditumbuhkan dalam media LB yang diberi $\mathrm{CuSO}_{4}$ untuk menjaga resistensi bakteri tersebut terhadap logam berat ${ }^{(13)}$.

Berdasarkan Gambar 3, dapat disimpulkan bahwa secara keseluruhan presentase penurunan kandungan logam berat tertinggi adalah perlakuan konsorsium bakteri Acinetobacter sp. IrC1 dengan Acinetobacter sp. IrC2 (66,66\%:33,33\%) dengan interval penurunan kandungan logam berat $(\mathrm{Zn}, \mathrm{Fe}$, dan $\mathrm{Mg}$ ) pada hasil perairan (udang jerbung, cumi, dan ikan mujair) adalah 91,69 hingga 99,82\% dengan rata-rata sebesar $97,87 \%$. Hasil konsorsium bakteri lebih tinggi dibandingkan dengan hasil penelitian bakteri tunggal. Acinetobacter sp. IrC2 yang dapat menurunkan konsentrasi Zn sebesar $67 \%{ }^{(22) \text {. }}$ 
Zn

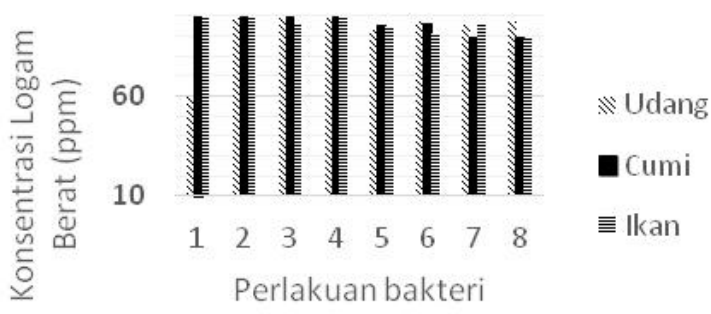

$\mathrm{Fe}$

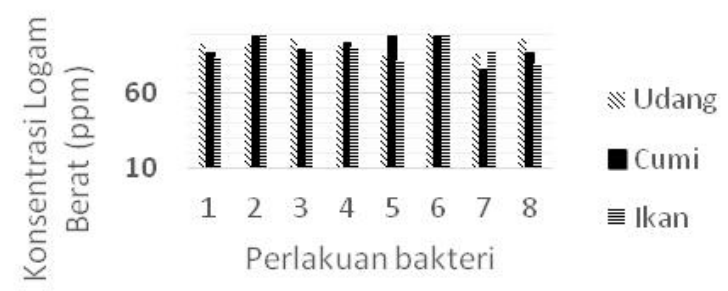

$\mathrm{Mg}$

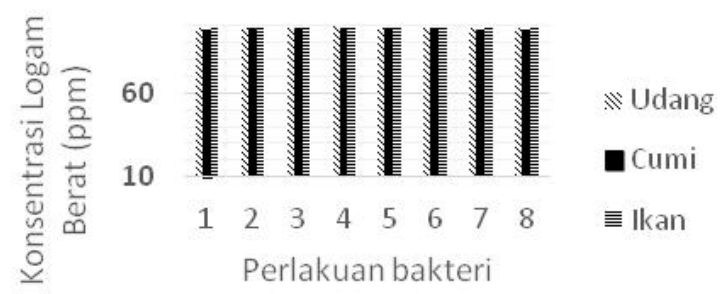

Gambar 3. Pengaruh konsorsium bakteri terhadap penurunan konsentrasi logam berat $\mathrm{Zn}, \mathrm{Fe}$, dan $\mathrm{Mg}$

Keterangan:

1. Acinetobacter sp. IrC1 (100\%)

2. Acinetobacter sp. IrC2 $(100 \%$

3. Acinetobacter pittii (100\%)

4. Acinetobacter sp. IrC1 : Acinetobacter sp. IrC2 (50\%:50\%)

5. Acinetobacter sp. IrC1 : Acinetobacter sp. IrC2 $(33,33 \%: 66,66 \%)$

6. Acinetobacter sp. IrC1 : Acinetobacter sp. IrC2 $(66,66 \%: 33,33 \%)$

7. Acinetobacter sp. IrC1 : Acinetobacter sp. IrC2 (40\%:60\%)

8. Acinetobacter sp. IrC1 : Acinetobacter sp. IrC2 (60\%:40\%)

Seluruh presentase penurunan logam berat tergolong tinggi yaitu rata-rata $90 \%$ pada setiap perlakuan bakteri, hal ini disebabkan adanya kombinasi dari proses biosorpsi dan bioakumulasi. Penurunan kandungan logam berat pada hasil perairan dapat terjadi karena bakteri yang digunakan memiliki kemampuan biosorpsi dan bioakumulasi $i^{(13)}$. Biosorpsi adalah penyerapan logam berat oleh organisme, secara pasif (menggunakan pertukaran ion dan pembentukan kompleks antara logam dan bakteri) dengan keadaan bakteri yang mati atau hidup ${ }^{(10)}$. Bioakumulasi adalah penumpukan atau akumulasi senyawa kimia di dalam tubuh mikroorganisme, secara aktif (dengan berbagai cara seperti masuk di rantai makanan mikroorganisme) dengan keadaan bakteri hidup ${ }^{(8)}$. Proses biosorpsi dan bioakumulasi terhadap logam-logam yang terdapat di dalam hasil perairan dapat terjadi karena bakteri mempunyai sifat resistensi logam berat ${ }^{(23)}$.

\subsection{Gambaran Aplikasi Hasil Penelitian}

Hasil penelitian tentang peranan konsorsium isolat bakteri resisten logam berat untuk menurunkan kandungan $\mathrm{Zn}$, Fe, dan $\mathrm{Mg}$ pada cumi, udang, dan ikan masih merupakan penelitian dasar yang bertujuan untuk mengetahui perbandingan konsorsium isolat bakteri terbaik. Untuk aplikasi hasil penelitian perlu dilakukan penelitian terapan dengan menginokulasikan $10 \%$ volume/volume kultur bakteri konsorsium terpilih dengan perbandingan konsorsium terbaik ke dalam bioreaktor yang berisi ikan atau cumi atau udang segar. Selanjutnya, perlu dilakukan penelitian terapan dengan memasukkan cumi, udang, dan ikan ke dalam bioreaktor dengan harapan terjadinya penurunan konsentrasi $\mathrm{Zn}$, $\mathrm{Fe}$, dan $\mathrm{Mg}$ yang terdapat pada biota laut tersebut. Diharapkan konsorsium bakteri yang terbukti dapat melakukan bioadsorbsi pada cumi, udang, dan ikan dalam bentuk sampel yang sudah dihaluskan juga dapat mereduksi konsentrasi logam berat ketika sampel dalam keadaan hidup.

Acinetobacter $s p$ IrC1, Acinetobacter $s p$. IrC2, dan Acinetobacter pittii merupakan bakteri yang bersifat infeksius tetapi berpotensi mereduksi konsentrasi logam berat. Belum ada rekomendasi dari FDA USA untuk menggunakan bakteri ini dalam sampel makanan. Penelitian ini merupakan penelitian awal yang diharapkan merupakan solusi mengatasi pencemaran logam berat pada produk bahan mentah udang, cumi, ikan. Penelitian lanjutan diperlukan untuk mengisolasi gen yang berperan dalam mengikat logam berat pada bakteri isolat kemudian diinsersikan ke dalam bakteri non patogen yang akan diaplikasikan pada produk perairan.

\section{KESIMPULAN}

Bakteri Acinetobacter sp. IrC1, Acinetobacter sp. IrC2, dan Acinetobacter pittii memiliki fase adaptasi saat jam ke 0-2, fase eksponensial saat jam ke 2-4 dan memasuki fase stasioner mulai jam ke 4. Hasil data pada 
penelitian ini hanya valid pada sampel hasil perairan di TPI Muara Kamal, Jakarta Utara. Kandungan logam berat yang diuji pada sampel perairan ada sembilan antara lain $\mathrm{Cd}$, Co, $\mathrm{Cr}$, $\mathrm{Cu}, \mathrm{Hg}, \mathrm{Fe}, \mathrm{Pb}, \mathrm{Zn}$, dan Mg. Logam berat Zn, $\mathrm{Fe}$, dan $\mathrm{Mg}$ memiliki nilai yang lebih besar dari pada keenam logam berat lainnya yaitu berkisar antara 8 ppm sampai 50 ppm.

Rata-rata presentase penurunan pada semua sampel dengan masing-masing logam berat dan perlakuan bakteri sebesar 94.96\%. Konsorsium bakteri terpilih adalah Acinetobacter sp. IrC1 dengan Acinetobacter sp. IrC2 (66,66\%:33,33\%) dengan interval penurunan kandungan logam berat ( $\mathrm{Zn}, \mathrm{Fe}$, dan $\mathrm{Mg}$ ) pada hasil perairan (udang jerbung, cumi, dan ikan mujair) adalah 91,69 hingga 99,82\% dengan rata-rata sebesar $97.87 \%$. Bakteri komersil Acinetobacter pittii menunjukkan hasil penurunan kandungan logam berat $(\mathrm{Zn}$, Fe, dan $\mathrm{Mg}$ ) pada hasil perairan (udang jerbung, cumi, dan ikan mujair) yang lebih rendah dibandingkan dengan bakteri konsorsium terpilih dengan interval 87,87 hingga 99,50\% dengan rata-rata sebesar $96,17 \%$.

\section{PERSANTUNAN}

Ucapan terimakasih diberikan kepada Kementerian Riset, Teknologi, dan Pendidikan Tinggi Republik Indonesia yang telah memberikan dana penelitian melalui proyek penelitian produk terapan atas nama Dr. Ir. Wahyu Irawati, M.Si dengan judul pemanfaatan konsorsium isolat bakteri multiresisten logam berat sebagai biosorben logam berat dalam bioreaktor logam berat dalam bioreaktor limbah cair. Terimakasih juga diberikan kepada Greis Naningsi mahasiswa Fakultas IImu Pendidikan Universitas Pelita Harapan atas bantuannya selama penulisan artikel ini.

\section{DAFTAR PUSTAKA}

1. BPLHD. (2013). Laporan Status Lingkungan Hidup Daerah Provinsi Daerah Khusus Ibukota Jakarta, Indonesia. Badan Pengelola Lingkungan Hidup Daerah DKI Jakarta, Indonesia.

2. PTPIN. (2014). Pengembangan Terpadu Pesisir Ibukota Negara, cetakan pertama. Kementrian Koordinator Bidang Perekonomian, Jakarta.

3. Kompas. (2017). Butuh Tindakan Bersama Atasi Pencemaran Laut. Tersedia dari: www.kompasiana.com. Diakses pada: 1 November 2017.

4. Fernanda, L. (2012). Studi kandungan logam berat timbal $(\mathrm{Pb})$, nikel $(\mathrm{Ni})$, kromium $(\mathrm{Cr})$, dan kadmium (Cd) pada kerang hijau (Perna viridis) dan sifat faksionasinya pada sedimen. Skripsi, Universitas Indonesia, DepokIndonesia.

5. KMNLH. (2004). Baku mutu air laut. Keputusan Menteri Negara Lingkungan Hidup., KEP. MEN. L.H NO: 51 TAHUN 2004.

6. Sarjono, A. (2009). Analisis kandungan logam berat $\mathrm{Cd}, \mathrm{Pb}$, dan $\mathrm{Hg}$ pada air dan sedimen di perairan Kamal Muara, Jakarta Utara. Skripsi, Institut Pertanian Bogor, Bogor-Indonesia.

7. IADC/CEDA. (1997). Dredged material disposal in the sea. Cited in Sarjono, A. 2009. Analisis kandungan logam berat $\mathrm{Cd}, \mathrm{Pb}$, dan $\mathrm{Hg}$ pada air dan sedimen di perairan Kamal Muara, Jakarta Utara. Skripsi, Institut Pertanian Bogor, Bogor-Indonesia.

8. Hakim, A.L. (2016). Bioakumulasi logam berat kadmium $(\mathrm{Cd})$ pada udang windu (Penaeus monodon) di tambak tradisional Kecamatan Jabon, Kabupaten Sidoarjo. Skripsi, Universitas Airlangga, Surabaya-Indonesia.

9. Mamaribo, H., Rompas, R.J., \& Kalesaran, O.J. (2015). Determinasi kandungan cadmium (Cd) di perairan Pantai Malalayang Sekitar Rumah Sakit Prof Kandou Manado. Jurnal Budidaya Perairan. 3(1): 114-118.

10.Priadie, B. (2012). Teknik bioremediasi sebagai alternatif dalam upaya pengendalian pencemaran air. Jurnal IImu Lingkungan. 10(1): 38-48

11.Irawati, W., Parhusip, A.J.N., Christian, S., \& Yuwono, T. (2017). The potential capability of bacteria and yeast strains isolated from Rungkut Industrial Sewage in Indonesia as a bioaccumulators and biosorbents of copper. Biodiversitas. 18(3): 971-977.

12. Kurniawan, A. \& Ekowati, N. (2016). Review: mikoremediasi logam berat. Jurnal Bioteknologi \& Biosains Indonesia. 3(1): 36-45.

13. Irawati, W. \& Parhusip, A.J.N. (2018). Growth characteristics and copper accumulation of bacterial consortium Acinetobacter sp. and Cupriavidus sp. isolated from a wastewater treatment plant. Biodiversitas. 19(5): 18841890.

14. Irawati, W., Yuwono, T., Soedarsono, J., \& Hartiko, H. (2012). Molecular and physiological characterization of copperresistant bacteria isolated from activated sludge in an industrial wastewater treatment plant in Rungkut-Surabaya, Indonesia. Microbiology Journal. 6(3): 107-116.

15. Victoria, T. (2017). Potensi Steptococcus thermophilus dan Lactobacillus plantarum 
pada proses pembuatan minuman fermentasi sari terung ungu (Solanum melongena L.). Skripsi, Universitas Pelita Harapan, Tangerang-Indonesia.

16. SNI. $\left(2009^{b}\right)$. Air dan air limbah-cara uji logam berat secara Spektrofotometri Serapan Atom (SSA). Standar Nasional Indonesia., SNI 6989:2009.

17. Novirisandi, R. (2012). Kajian viabilitas dan pola pertumbuhan Lactobacillus plantarum pada variasi konsentrasi molase dan waktu inkubasi. Skripsi, Universitas Airlangga, Surabaya-Indonesia.

18.SNI. (2011). Cara uji kimia-bagian 5: penentuan kadar logam berat timbal $(\mathrm{Pb})$ dan kadmium (Cd) pada produk perikanan. Standar Nasional Indonesia., SNI 2354.5:2011.

19. Indian Council of Medical Research (ICMR). (2017). "Indian Food Composition Tables". National Institute of Nutrition, India.
20. United States Department of Agriculture. (2016). National Nutrient Database for Standard Reference Release 28. Available from:

https://ndb.nal.usda.gov/ndb/search/list?SYN CHRONIZER_TOKEN=802827cf-8f27-4592a05f-

763ffb2f8744\&SYNCHRONIZER_URI=\%2Fnd b\%2Fsearch\%2Flist\&qt=\&ds=Standard+Refer ence\&qlookup $=\&$ manu $=$. Accessed 2017 November 27.

21. Ika, Tahril, \& Said, I. (2012). Analisis logam timbal $(\mathrm{Pb})$ dan besi (Fe) dalam air laut di wilayah Pesisir Pelabuhan Ferry Taipa Kecamatan Palu Utara. Jurnal Akademi Kimia. 1(4): 181-186.

22. Irawati, W., Parhusip, A.J.N., \& Sopiah, R.N (2015). Heavy metals biosorption by copper resistant bacteria of Acinetobacter sp. IrC2. Microbiology Indonesia. 9(4): 163-170.

23. Zarkasyi, H. (2008). Biosorpsi logam merkuri $(\mathrm{Hg})$ oleh Bacillus megaterium asal hilir Sungai Cisadane. Skripsi, Universitas Islam Negri Syarif Hidayatullah, Jakarta-Indonesia. 